\title{
EMPIRICAL RESEARCH ON CORPORATE SOCIAL RESPONSIBILITY AND ITS MANAGEMENT
}

\author{
Leontin STANCIU*, Cristian-Lucian STANCIU** \\ *"Nicolae Bălcescu" Land Forces Academy Sibiu, Romania \\ ** S.C. Marquard Schaltsysteme S.C.S., Sibiu, Romania \\ leontinstanciu@yahoo.com, stanciu_cristian_ro@yahoo.com
}

\begin{abstract}
In the context of a modern economy, maximizing the value of economic entities cannot be achieved only through basic activities. The fulfillment of this strategic objective implies the conduct of other types of activities bearing a social impact, brought together under the concept of corporate social responsibility. In this context, the authors intend to empirically investigate the social responsibility, both in terms of concept, evolution, and management, at the level of the economic entities and to argue the necessity of extending it at a microeconomic level for a sustainable development.
\end{abstract}

Keywords: corporate social responsibility, economic entity, corporate responsibility management, local community, sustainable development.

\section{Introduction}

In the context of the economic globalization, of a particularly dynamic external environment, the competitiveness of the economic entities largely depends on the quality of their management, on its ability to interpret, in an integrative approach, the socio-economic phenomena and processes and to optimally adapt to the market trends. Currently, the economic entities are assessed both in terms of the quality of their products, their economic and financial results, and their contribution to the life of the communities they belong to, the social responsibility they undertake. At an international level, more and more economic entities have become aware of the need and the benefits of engaging in activities specific to the communities in which they function, for their sustainable development. At the same time, we notice that in the recent years, an increasingly significant percentage of the budget of many economic entities has been allocated to the social responsibility, which was required for the achievement of the established strategic objectives.

For these reasons, we consider that an important component of the strategic management of an economic entity is the management of its social responsibility.

\section{Theoretical Approaches to the Concept of Corporate Social Responsibility (CSR).} The quintessence of the concept of corporate social responsibility was highlighted suggestively by the American poet Maya Angelou as follows:

"I've learned that you should not go through life with a catcher's mitt on both hands; you need to be able to throw something back". This belief is, in fact, an invitation to introspection, to the correct 
understanding of the mechanisms underlying our actions, or, better said, of the biblical myth of the good and doing good.

Any economic entity is a legal person. The concept of corporate social responsibility emphasizes the dimension of "person" to the detriment of that of "legal". In its capacity of "person", the economic entity is an inhabitant of a citadel, of a local community, having both rights and responsibilities. The starting point of each economic entity when becoming a "corporate citizen" is that the welfare of the community in which it operates directly influences its results and its evolution. In this context, we assert that corporate social responsibility must become a natural component of the social and economic life in Romania and that economic entities must assume the responsibility to interact actively and positively with their clients, with the external environment and with their own employees. In fact, what is corporate social responsibility? It is the care for the environment, the relationship with the employees, the civilized working conditions, the appropriate occupational health and safety measures, the facilities offered to employees for their training and professional development, the fairness in the relationship with the business partners, the transparency of the entity's activities towards employees, clients, community and administration, and, last but not least, the involvement in the community life.

Any economic entity can take on social responsibilities through the activities that it carries out, such as:

- $\quad$ production of safe and high-quality goods;

- correct and complete consumer information;

- implementation of production technologies to reduce the air pollutant emissions resulting from the technological processes, and so on[1].
Over time, the gap between the social performance of the economic entities and the social expectations has increased, even though the social performance has improved. As these expectations continuously rise, we consider that the managers must be permanently sensitive and receptive to the social matters, while efficiently managing the entities they run [2].

The first debates on the concept of Corporate Social Responsibility (CSR) took place in the early $1950 \mathrm{~s}$ in the academic world.

Initially promoted under the name of "social responsibility", the concept highlighted in particular the expectations the communities had from the business environment and the ethical obligations of the economic entities towards them. Thus, Howard Bower, considered to be "the father" of CSR, defined the concept as "the businessmen's obligations to pursue those policies, to make those decisions, or to follow those directions that are agreed in terms of values and objectives by our society"[3].

If until the 1970s mainly the businessmen's responsibility was highlighted, later on, the emphasis was laid on the social responsibility of the economic organizations. Thus, H. L. Johnson argues that a company should not seek only to maximize profits, but also employees, suppliers, communities and society [4].

A.B. Carroll had an important contribution to clarifying the concept of corporate social responsibility, claiming that CSR is made up of four key pillars: economic, legal, ethical and philanthropic. By calling them "the pyramid of corporate social responsibility," the four key pillars of CSR are explained as follows:

- economic- it highlights the responsibility of the economic organizations to maximize their profit from the production of goods and services needed by the society; 
- legal- it highlights the responsibility of the management of the economic organizations to comply with the normative framework;

- ethical- it highlights the "behavior" and the responsibility of the companies to comply with the social norms not coded by laws but expected by the "actors" functioning in the society;

- philanthropic- it highlights the voluntary involvement of the economic organizations in helping the community they belong to [5].

The European Commission defines this concept as the patrimonial entities' voluntary integration of certain social and environmental issues of the communities in which they operate in their economic activity and in their relation to the interest groups. Practically, from this definition, we can identify three aspects that characterize the corporate social responsibility, such as:

- it is a voluntary action of the economic entities;

- it implies a three-dimensional approach: economical, social and environmental;

- it relates to the interest groups of the economic entities ("stakeholders").

In the literature, three main categories of corporate social responsibility are mentioned:

a) the social obligation;

b) the social reaction;

c) the social sensitivity[6].

a) As a social obligation, the corporate responsibility is supported by the following arguments:

- the first argument- the management of an economic entity has the major responsibility to maximize the wealth of the shareholders;

- the second argument- the activities bearing a social impact (social programs) must be regulated by law, by public policies and by actions/contributions of private individuals; in this context, the economic entities contribute by paying taxes to financially supporting these activities;

- the third argument- by allocating certain amounts of money from the obtained profit in order to support social impact activities, the management of the economic entity affects the interests of its owners as it takes a part of their income; at the same time, financing non-profit activities is not an approach desired by the owners/ shareholders;

- the fourth argument- over time, the costs of the activities/actions bearing a social impact may generate an increase of the prices of goods marketed by the entity and their consumers will ultimately pay the bill of the social efforts made by the entity.

b) Social response is another form of manifestation of the social responsibility, being generated by the fact that society as a whole needs to receive more from the economic entities than their goods and services. Practically, an economic entity must be liable for the environmental and social costs it generates, and, on the other hand, it must contribute to solving the community's problems, including those that cannot be attributed to them.

The social responsibility as a social response implies only voluntary actions conducted by the economic entities.

Keith Davis, a management specialist, claims that an economic entity is not socially responsible when it confines itself to meeting the social requirements stipulated by the effective legislation [7]. Practically, corporate social responsibility means more than that.

c) Social sensitivity implies a socially responsible preventive and preemptive behavior, materialized in:

- contributing to solving the social problems (awarding scholarships to youth from the local schools, supporting the launch of small businesses within the 
community in order to create jobs in the area, etc.)

- anticipating the future needs of the community and proactively involving in meeting them;

- creating and maintaining a constructive communication with the public authorities;

- promoting legislative initiatives to improve the legal framework with significant social impact, and so on.

\section{The Beneficiaries of the Corporate Social Responsibility}

In order to achieve socially responsible actions, the economic entities must precisely identify their beneficiaries. In the practice of the corporate social responsibility, there are two main categories of beneficiaries, namely internal and external:

a) The internal beneficiaries: - clients, employees, and equity owners have immediate, divergent and sometimes conflicting interests.

In relation to the customers, the responsibilities of an economic entity derive from the social obligations depending on the characteristics of its products (quality, safety, packaging, etc.)

In relation to the employees, the responsibilities of the entity are, first of all, those stipulated by the labor law. In addition to the legal responsibilities, the entity may extend the scope of the social impact activities by granting a series of benefits to its own employees (such as health, hospitalization or accident insurance, supplementary pension funds, and more.)

In relation to the equity owners, the responsibility of the entity's management is to fairly and correctly present to its shareholders the way the resources were used and the results that were obtained.

b) The external beneficiaries may be specific and common. Both categories benefit, directly or indirectly, from the effects of the social impact actions conducted by the economic entities.

Modern society includes a great diversity of groups with specific interests (national minorities, elder people, women, young people, unemployed, etc.) and their main objective is the elimination of all discrimination. Foundations, government institutions, professional organizations and associations, as well as economic entities act in support of these groups of specific beneficiaries. The latter perform obligatory, reactive or affective actions.

Programs for joint external beneficiaries are a way of effectively implementing social responsibility, through which the economic entities contribute to preventing or solving the social problems of their communities.

\section{Corporate Social Responsibility in Romania- An Empirical Approach.}

In Romania, corporate social responsibility has become a reality after the year 2000 , and a major factor in its emergence was the increase in the number of multinational companies. Practically, these economic entities have made a transfer of the organizational culture to the local communities where they function. Initially, corporate social responsibility in Romania has been valued especially for its commercial qualities and less for its ethical ones. Subsequently, activating in a competitive economic environment, more and more entities valued the role of CSR in the process of building and consolidating their own image and reputation in the medium and long term. Social responsibility is not only a tool for capitalizing companies through image building, but also a guarantee of long-term success, directly linked to the social and environmental performance of the local communities. [8] In Romania, the promotion of CSR is achieved through various strategies developed by the multinational companies globally, 
sometimes adapted to the specifics of the local communities but without a consistent creative component. Thus, the main standard CSR programs target:

- supporting social assistance activities;

- making donations to local communities;

- sponsoring social impact activities/actions;

- funding scientific research projects, educational and environmental programs, and so on.

According to the study called "CSR Trends and Realities in Romania", conducted by CSRMedia.ro and Ernst\&Young Romania, corporate social responsibility borrows increasingly more from the global specific dynamism, the management of the Romanian companies realizing its role in maximizing their value and achieving a sustainable local development. Thus, $78 \%$ of the respondents stated that the entity they represent has a strategy dedicated to CSR, and 67\% believe that the general interest towards CSR has increased over the past 12 months. Also, over $75 \%$ of the respondents said they have an annual budget dedicated to CSR actions [9]. Over time, a number of specific CSR programs have been developed by companies such as: Enel Romania, OMV, Orange Romania, Petrom, Coca-Cola HBC Romania, Romgaz, Unilever Romania, Dacia Groupe Renault, BCR, BRD-Groupe Societe Generale, Danone Romania, and others.

\section{Specifics of the Corporate Social Responsibility Management.}

At the level of the economic entity, the strategic management optimally combines its internal resources, depending on the market constraints, in order to maximize the value added to all the conducted activities and, ultimately, to achieve sustainable development. Until the mid-twentieth century, for the economic entities, the notion of added value had only an economic meaning and targeted the profit margin that went to the shareholders. Gradually, this vision of the results of the economic entities' activity has changed. Thus, the entity has been perceived as an integrated economic, social and environmental system in which its results have an economic and financial added value, a social and cultural one and another related to the environment.

In this approach, more and more specialists claim that corporate social responsibility management is an important dimension of the strategic management of the economic entity. Corporate social responsibility management, as an integral part of the strategic management, aims at designing, monitoring and assessing social, cultural and environmental performance of the economic entity, with measurable indicators as the added value to the welfare of the society, to the preservation and the development of the cultural treasure of the communities, to the preservation of the biodiversity and the natural environment [10]. At present, referring to the meanings of the two concepts, we consider that strategic management aims to achieve the added value of the economic entity in general, and the social responsibility management addresses the value of its impact on the people and their natural and socio-cultural environment. The main argument justifying the open and voluntary option for a socially responsible management is based on the principle of reciprocity. Thus, corporate social responsibility is practically what the economic entities return to the local communities for their permission to access their specific resources. On the other hand, the exercise of an efficient corporate social responsibility management is a guarantee of the stability, the endurance and the sustainable development of the communities. 


\section{Conclusions}

Under the current economic conditions, we consider that the economic entities, in order to maximize their value, should not be limited to their basic activity. Through global practices and strategies tailored to a versatile and dynamic economic environment, through intelligent corporate responsibility management, through consistent promotion of social responsibility projects adjusted to the needs of all the beneficiaries, the value and the reputation of the economic entities will increase considerably.

In a knowledge-based economy, corporate social responsibility lies in interdependence with knowledge management [11]. These are no longer attributes of the economic entities, but also basic conditions of an open and efficient market. We also believe that by promoting social responsibility, the economic entities actually contribute to the sustainable development of the communities and the society as a whole, with nothing but benefits for all the parties involved.

\section{References}

[1] Militaru, Gh., Comportament organizațional, Bucharest, Economic Publishing House, 2005, pp.147.

[2] Popescu,D., Comportament organizațional, $2^{\text {nd }}$ revised edition, Bucharest, ASE Publishing House, 2013, pp.395.

[3] Bowen, H., Toward Social Responsabilities of the Businessman, New York: Harper and Row, 1953.

[4] Stancu, A., Marketing și responsabilitate socială, Bucharest, ASE Publishing House, 2012, pp.27-28.

[5] Burton, B. and Goldsbey M., Corporate Social Responsibility Orientation, Goals and Behavior: A study of Small Business Owners, Business and Society, vol.48;88; 2009, pp.89, SAGE.

[6] Militaru, Gh., op.cit., pp.148.

[7] Keith, D., The Case for and against Business Assumption of Social Responsibilities, Academy of Management Journal, June 1973, pp.313.

[8] Diniță, Al., Responsabilitatea corporativă $\hat{\imath}$ România- de unde și încotro? at www.responsabilitateasocială.ro/editoriale.

[9] CSRMedia, Primul studiu despre Responsabilitatea Corporativă în România ca instrument strategic, at http://www.csrmedia.ro.

[10] Brișcaru,A., Globalizare etică. Responsabilitate socială corporativă, Iași, European Institute, 2012, pp.144.

[11] Hristea, A.M, Responsabilitaea socială corporativă-între deziderat și realitate, "Economia teoretică și aplicată” Magazine, vol. XVIII (2011), No.10 (563), pp.73. 